\title{
Effects of Demographic Characteristics of Logistics Firms on Their Performance and Job Satisfaction of Their Employees
}

\author{
Mehmet Miman, Zeki Uyan, Linda Küçük \\ Toros University, Mersin, Turkey \\ Umut Güloğlu \\ Osmaniye Korkut Ata University, Osmaniye, Turkey
}

\begin{abstract}
This study investigates the effects of demographic factors of the logistics firms' employees (gender, age, education level, experience level, and department) on their job satisfaction and the effects of demographic factors of the logistics firms (company type, capital nature, and company experience level) on their performance of logistics activities about information technologies, interior relationship, and transportation based on the scale developed by the same authors and the sample of 39 logistics firms selected randomly in the city of Mersin and Adana in Turkey. According to findings, none of the demographic factors of the employees does affect their job satisfaction. In terms of the demographic factors of the logistics firms, their experience level in the field is found to be significant in their logistics activities about information technology. In general, as the firm's experience increases, they perform better on information technology.
\end{abstract}

Keywords: logistics, performance, job satisfaction, demographic factors

\section{Introduction}

This study analyzes the effects of characteristics (demographic variables) of logistics firms on their performance and job satisfaction of their employees based on the scale developed by Güloğlu, Miman, Küçük, and Uyan (2014). The scale they developed measures the performance of logistics firms on information technologies, interior relationships, transportation, and Job satisfaction.

A study in the literature (Chow, Heaver, \& Henriksson, 1994) concerns the definition and measurement of performance in logistics research. It concludes that there is a variety of constraints which make it difficult to draw broad inferences from the literature about the relationship between a given logistics strategy and performance. Another study (Lai, Ngai, \& Cheng, 2002) aims to investigate the construct of and develop a measurement instrument for supply chain performance (SCP) in transport logistics. Based on the supply chain operations reference model and various established measures, a measurement model and a measurement instrument for SCP in transport logistics are developed. A 26-item SCP measurement instrument was

Mehmet Miman, Ph.D., assistant professor, Toros University, Mersin, Turkey.

Zeki Uyan, senior student, Toros University, Mersin, Turkey.

Linda Küçük, M.Sc. student, instructor inToros University, Mersin, Turkey.

Umut Güloğlu, M.Sc., instructor in Osmaniye Korkut Ata University, Osmaniye, Turkey.

Correspondence concerning this article should be addressed to Mehmet Miman, Toros University, Bahçelievler Mahallesi 16. cadde No:1/7, 33140 Yenişehir/Mersin, Türkiye. E-mail: mehmet.miman@toros.edu.tr. 
constructed, reflecting service effectiveness for shippers, operations efficiency for transport logistics service providers, and service effectiveness for consignees. They claim that their measurement instrument is reliable and valid for evaluating SCP in transport logistics. Moreover, Günaşekaran, Patel, and Tırtıroğlu (2001) claimed that in today's world, supply chain management (SCM) is a key strategic factor for increasing organizational effectiveness and better realization of organizational goals such as enhanced competitiveness, better customer care, and increased profitability. It is argued that most of these companies realize that, in order to evolve an efficient and effective supply chain, SCM needs to be assessed for its performance. They develop a framework for measuring the strategic, tactical, and operational level performance in a supply chain. In addition, a list of key performance metrics is presented. The emphasis is on performance measures dealing with suppliers, delivery performance, customer-service, and inventory and logistics costs in a SCM. In developing the metrics, an effort has been made to align and relate them to customer satisfaction.

Performance measurement is found critical to the success of almost any organization, because it creates understanding, molds behavior, and leads to competitive results (Fawcett \& Cooper, 1998). Moreover, a world-class performance requires superior process measurement both within the firm and across organizational boundaries. A model in the literature (Zhao, Dröge, \& Stank, 2001) portrays customer-focused and information-focused capabilities as interrelated predictors of firm performance. It is illustrated that customer-focused capabilities are directly related to performance, but that information-focused capabilities are not. Rather, the latter relationship is indirect: Information-focused capabilities are linked to performance via the interrelationship with customer-focused capabilities.

Based on the literature, performances of logistics firms on information technology, interior relationship, and transportation are focused on this study. Moreover, in order to investigate the relationship among these performances, another metric is included as job satisfaction. Job satisfaction or employee satisfaction has been defined in many different ways (URL-1). Some believe that it is simply how content an individual is with his or her job, in other words, whether or not they like the job or individual aspects or facets of jobs, such as nature of work or supervision.

\section{Scale Used}

The scale used on this study is developed by Güloğlu et al. (2014) and its reliability is computed based on a random sample of 39 logistics. The majority (71.8\%) of their sample's members are male. Approximately half of the sample (48.7\%) aged between 30 and 39 years old. This is followed by members of age of 20-29 years old (35.9\%) and 40-49 years old (15.4\%). The vast majority of the samples $(82.1 \%)$ have an undergraduate level of education. The most of the sample (each is $33.3 \%$ ) has the experience of $0-3$ years and eight years or above. This is followed by an experience level of $4-5$ years and 6-7 years $(20.5 \%$ and $12.8 \%$ respectively). The majority of the samples (43.6\%) are working at the operations management department. This is followed by sales and marketing department $(23.1 \%)$.

Most of the logistic firms took place in the sample (48.7\%), which are limited companies. This is followed by joint-stock companies (41\%). Most of the companies in the sample (69.2\%) have a domestic capital nature. The companies $(43.6 \%)$ in the sample have an experience of 16 years or above as a logistics firm. This is followed by companies of experience of between eight and 15 years $(25.6 \%)$.

This study, based on the same sample selected by Güloğlu et al. (2014) and applied to 39 employees from 39 logistics firms operated in the city of Adana and Mersin in Turkey, tests the effects of gender, age, education 
level, experience level, and department of logistics firms' employees on their job satisfaction and effects of company type, capital nature, and company experience level of the logistics firms on their performance of logistics activities about information technology, interior relationship, and transportation.

Based on Güloğlu et al. (2014), the scale developed and used in this study consists of 20 items with the internal consistency of 0.888 . Furthermore, the reliability would not improve much, if any of these items were removed. All the items are related to each other and necessary for the scale (the corrected item total correlations are greater than 0.20 ). The sub-dimensions, associated items and Cronbach's alpha values are presented in Table 1.

Table 1

Sub-dimensions of the Scale

\begin{tabular}{lcl}
\hline Dimension & Items & Cronbach's Alpha \\
\hline Information technology & $1-4$ & 0.594 \\
Interior relationship & $5-9$ & 0.679 \\
Transportation & $10-14$ & 0.763 \\
Job satisfaction & $15-20$ & 0.830 \\
Overall & $1-20$ & 0.888 \\
\hline
\end{tabular}

The means and standard deviations of each item (out of five) are given in Table 2.

Table 2

Item Statistics

\begin{tabular}{llllll}
\hline Item & $N$ & Minimum & Maximum & Mean & Standard deviation \\
\hline I1 & 39 & 2.00 & 5.00 & 4.4872 & 0.82308 \\
I2 & 39 & 1.00 & 5.00 & 4.2564 & 1.11728 \\
I3 & 39 & 1.00 & 5.00 & 3.8718 & 1.30141 \\
I4 & 39 & 1.00 & 5.00 & 4.0000 & 0.94591 \\
I5 & 39 & 1.00 & 5.00 & 3.9744 & 1.40464 \\
I6 & 39 & 5.00 & 4.0513 & 0.91619 \\
I7 & 39 & 1.00 & 5.00 & 3.8462 & 0.93298 \\
I8 & 39 & 3.00 & 5.00 & 4.4103 & 0.59462 \\
I9 & 39 & 3.00 & 5.00 & 4.1538 & 0.70854 \\
I10 & 39 & 3.00 & 5.00 & 3.9487 & 0.97194 \\
I11 & 39 & 5.00 & 4.5128 & 0.55592 \\
I12 & 39 & 5.00 & 4.2564 & 1.06914 \\
I13 & 39 & 5.00 & 4.1795 & 0.85446 \\
I14 & 39 & 5.00 & 4.0513 & 1.12270 \\
I15 & 39 & 1.00 & 5.00 & 4.2308 & 0.62667 \\
I16 & 39 & 3.00 & 5.00 & 3.8974 & 0.91176 \\
I17 & 39 & 5.00 & 4.0000 & 0.76089 \\
I18 & 39 & 2.00 & 5.00 & 3.4359 & 0.82062 \\
I19 & 39 & 2.00 & 5.00 & 3.3590 & 0.66835 \\
I20 & 39 & 2.00 & 5.00 & 3.8462 & 0.93298 \\
\hline
\end{tabular}

According to Table 2, the item with which the people in the sample agree most is I11 (customers are satisfactory with the delivery frequency, 4.51). This is followed by I1 (in the company, computer supporting communication is used, 4.48) and I8 (logistics strategy is compatible with the company's general strategy, 4.41). The least agreed item is found to be I19 (people obtained what they want in the work place, 3.35). 


\section{Research Methods}

To investigate the effects of gender, age, education level, experience level, and department of logistics firms' employees on their job satisfaction and effects of company type, capital nature and company experience level of the logistics firms on their performance of logistics activities about information technology, interior relationship and transportation, a set of hypothesis tests is conducted (independent sample $t$-tests for gender and one way ANOVA analysis for other demographic factors as the sample size is greater than 30 and can be assumed to be distributed normally).

\section{Research Results}

The results of these tests (associated $p$-values) are reported in Table 3 and Table 4.

Table 3

Effects of Demographic Factors on Job Satisfaction: P-values

\begin{tabular}{llllll}
\hline Demographic factor & Gender & Age & Education level & Experience level & Department \\
\hline Job satisfaction & 0.344 & 0.129 & 0.332 & 0.334 & 0.243 \\
\hline
\end{tabular}

According to Table 3, none of the demographic factors was found to be significant for job satisfaction of logistics firms' employees at the confidence level of $95 \%$.

Table 4

Effects of Demographic Factors on Logistics Firms' Performance: P-values

\begin{tabular}{llll}
\hline Demographic factor & Company type & Capital nature & Company experience level \\
\hline Information technology & 0.073 & 0.134 & $0.023^{*}$ \\
Interior relationship & 0.471 & 0.541 & 0.152 \\
Transportation & 0.145 & 0.230 & 0.131 \\
\hline
\end{tabular}

Note. *Significant at the confidence level of $95 \%$.

According to Table 4, among the demographic variables of logistics firms analyzed in this study, only company experience level is found to be a significant factor on the information technology performance of logistics company at the confidence level of $95 \%$. The details of the relationship can be observed in Table 5 .

Table 5

Effects of Company Experience Level on Information Technology Performance

\begin{tabular}{llrl}
\hline Company experience level & Mean & $\mathrm{N}$ & Std. deviation \\
\hline 0-3 years & 14.7143 & 7 & 4.07080 \\
4-7 years & 14.4000 & 5 & 2.50998 \\
8-15 years & 17.3000 & 10 & 2.35938 \\
16 years and above & 17.6471 & 17 & 1.96663 \\
Total & 16.6154 & 39 & 2.85266 \\
\hline
\end{tabular}

Table 5 reflects that in general, the more experience the logistics firms have, the better they perform on information technologies.

\section{Conclusions}

This study extends the preliminary study of Güloğlu et al. (2014), where a scale was developed and the relationship was revealed between the performance of logistics firms on information technology, interior 
relationship and transportation, and job satisfaction of their employees by using the same sample and scale and investigating the effects of demographic factors of the employees (gender, age, education level, experience level, and department) on their job satisfaction and the effects of demographic factors of the logistics firms (company type, capital nature, and company experience level) on their performance of logistics activities about information technology, interior relationship and transportation. According to findings, none of the demographic factors of employees does affect their job satisfaction. In terms of the demographic factors of the logistics firms, their experience level in the field is found to be significant on their logistics activities about information technology. In general, as the firm's experience increase, they better perform on information technology. Therefore, the young logistics firms should be encouraged in the use of information technologies in logistics operations as the performance on this affects the performance on other logistics activities such as interior relationship and transportation as well as job satisfaction of the firm's employees (Güloğlu et al., 2014)

This study can further extended by including other logistics firms in Turkey and other demographic factors of the firms.

\section{References}

Chow G., Heaver, T. D., \& Henriksson, L. E. (1994). Logistics performance: Definition and measurement. International Journal of Physical Distribution \& Logistics Management, 24(1), 17-28.

Fawcett, S. E., \& Cooper, M. B. (1998). Logistics performance measurement and customer success. Industrial Marketing Management, 27(4), 341-357.

Güloğlu, U., Miman, M., Küçük, L., \& Uyan, Z. (2014). The Effects of Performance of Logistics Firms on the Job Satisfaction of Their Employees, XII. Proceedings from International Logistics and Supply Chain Congress, İstanbul, Loder.

Günaşekaran, A., Patel, C., \& Tırtıroğlu, E. (2001). Performance measures and metrics in a supply chain environment. International Journal of Operations \& Production Management, 21(1/2), 71-87.

Lai, K., Ngai, E. W. T., \& Cheng, T. C. E. (2002). Measures for evaluating supply chain performance in transport logistics. Transportation Research Part E: Logistics and Transportation Review, 38(6), 439-456.

Zhao, M., Dröge, C., \& Stank, T. P. (2001). The effects of logistics capabilities on firm performance: Customer-focused versus information-focused capabilities. Journal of Business Logistics, 22(2), 91-107. 